\title{
Production, partitioning and stoichiometry of organic matter under variable nutrient supply during mesocosm experiments in the tropical Pacific and Atlantic Ocean
}

\author{
J. M. S. Franz ${ }^{1}$, H. Hauss ${ }^{1}$, U. Sommer ${ }^{1}$, T. Dittmar ${ }^{2}$, and U. Riebesell ${ }^{1}$ \\ ${ }^{1}$ GEOMAR Helmholtz Centre for Ocean Research Kiel, Düsternbrooker Weg 20, 24105 Kiel, Germany \\ ${ }^{2}$ Max Planck Research Group for Marine Geochemistry, University of Oldenburg, Institute for Chemistry and Biology of the \\ Marine Environment, Carl-von-Ossietzky-Str. 9-11, 26129 Oldenburg, Germany \\ Correspondence to: J. M. S. Franz (jfranz@geomar.de)
}

Received: 12 April 2012 - Published in Biogeosciences Discuss.: 15 May 2012

Revised: 25 October 2012 - Accepted: 27 October 2012 - Published: 20 November 2012

\begin{abstract}
Oxygen-deficient waters in the ocean, generally referred to as oxygen minimum zones (OMZ), are expected to expand as a consequence of global climate change. Poor oxygenation is promoting microbial loss of inorganic nitrogen $(\mathrm{N})$ and increasing release of sediment-bound phosphate (P) into the water column. These intermediate water masses, nutrient-loaded but with an $\mathrm{N}$ deficit relative to the canonical $\mathrm{N}: \mathrm{P}$ Redfield ratio of $16: 1$, are transported via coastal upwelling into the euphotic zone. To test the impact of nutrient supply and nutrient stoichiometry on production, partitioning and elemental composition of dissolved (DOC, DON, DOP) and particulate (POC, PON, POP) organic matter, three nutrient enrichment experiments were conducted with natural microbial communities in shipboard mesocosms, during research cruises in the tropical waters of the southeast Pacific and the northeast Atlantic. Maximum accumulation of POC and PON was observed under high $\mathrm{N}$ supply conditions, indicating that primary production was controlled by $\mathrm{N}$ availability. The stoichiometry of microbial biomass was unaffected by nutrient $\mathrm{N}$ : $\mathrm{P}$ supply during exponential growth under nutrient saturation, while it was highly variable under conditions of nutrient limitation and closely correlated to the $\mathrm{N}: \mathrm{P}$ supply ratio, although PON : POP of accumulated biomass generally exceeded the supply ratio. Microbial $\mathrm{N}: \mathrm{P}$ composition was constrained by a general lower limit of $5: 1$. Channelling of assimilated P into DOP appears to be the mechanism responsible for the consistent offset of cellular stoichiometry relative to inorganic nutrient supply and nutrient drawdown, as DOP build-up was observed to inten-
\end{abstract}

sify under decreasing $\mathrm{N}$ : $\mathrm{P}$ supply. Low nutrient $\mathrm{N}$ : $\mathrm{P}$ conditions in coastal upwelling areas overlying $\mathrm{O}_{2}$-deficient waters seem to represent a net source for DOP, which may stimulate growth of diazotrophic phytoplankton. These results demonstrate that microbial nutrient assimilation and partitioning of organic matter between the particulate and the dissolved phase are controlled by the $\mathrm{N}: \mathrm{P}$ ratio of upwelled nutrients, implying substantial consequences for nutrient cycling and organic matter pools in the course of decreasing nutrient $\mathrm{N}$ : $\mathrm{P}$ stoichiometry.

\section{Introduction}

Oxygen minimum zones (OMZs) of the tropics and subtropics occur in conjunction with highly productive eastern boundary upwelling systems, e.g. the Peru Current in the eastern tropical South Pacific (ETSP) and the Canary Current in the eastern tropical North Atlantic (ETNA). Nutrientrich deep water is transported by wind-driven upwelling vertically into the euphotic zone, ensuring high rates of primary production. Large amounts of sinking microalgal biomass enhance consumption of dissolved oxygen $\left(\mathrm{O}_{2}\right)$ in the mesopelagic zone indirectly via microbial degradation of organic matter (Helly and Levin, 2004). Besides these loss processes, deoxygenation is further promoted by a pronounced stratification of the upper water column off the upwelling centers, impeding ventilation of the $\mathrm{O}_{2}$-depleted intermediate water body (Reid, 1965; Luyten et al., 1983). 
Climate change-induced warming of the surface layer leads to an intensified stratification of the upper tropical ocean, and rising sea surface temperatures impede the uptake of atmospheric $\mathrm{O}_{2}$ by lowering its solubility (Keeling and Garcia, 2002; Matear and Hirst, 2003).

The impact of low $\mathrm{O}_{2}$ levels on redox-sensitive nutrient cycling is immense. Subanoxia or anoxia creates niches for the microbial processes of denitrification (Codispoti and Christensen, 1985) and anaerobic ammonium oxidation (anammox) (Thamdrup and Dalsgaard, 2002; Kuypers et al., 2003), both contributing to the deficit of biologically available inorganic nitrogen $(\mathrm{N})$ by converting it to nitrous oxide and/or dinitrogen $\left(\mathrm{N}_{2}\right)$. Decreasing oxygenation has also implications on phosphorus cycling. If bottom water and sediment become depleted in $\mathrm{O}_{2}$, buried metal oxide complexes are reduced and the associated dissolved inorganic phosphorus (P) is released back into the water column. A further source of $\mathrm{P}$ is the dissolution of apatite-containing fish debris in the sediments of the continental shelf areas. This process supplies additional $\mathrm{P}$ to the dissolved reactive $\mathrm{P}$ pool especially in the fish-rich waters of the ETSP (Suess, 1981; Van Cappellen and Berner, 1988).

These deoxygenation-induced changes in nutrient cycling are generating intermediate water masses with a low nutrient $\mathrm{N}: \mathrm{P}$ signature relative to the Redfield ratio of $16: 1$ (Redfield, 1958). Via coastal upwelling, these are transferred into the surface layer, fuelling primary production. An open question is how primary production will respond to OMZ-induced shifts in nutrient availability and the associated decline in nutrient $\mathrm{N}$ : P stoichiometry. The prevailing $\mathrm{N}$ limitation of phytoplankton within coastal upwelling systems suggests a decreasing trend of photoautotrophic production in the course of expanding OMZs (Dugdale, 1985). Modifications in the concentration of supplied nutrients are known to further affect the biochemical composition of phytoplankton (Gervais and Riebesell, 2001). Sterner and Elser (2002) introduced the "they are what they eat" theory, implying that phytoplankton $\mathrm{N}$ : P generally mirrors $\mathrm{N}$ : $\mathrm{P}$ supply. In contrast, studies involving dynamic nutrient models or field surveys claimed the specific growth strategy of phytoplankton being the key control of its elemental stoichiometry (Klausmeier et al., 2004b; Arrigo, 2005; Franz et al., 2012). This hypothesis is based on the fact that the different functional compartments within a phytoplankton cell are varying in their individual nutrient demands (Falkowski, 2000; Geider and LaRoche, 2002). Cellular stoichiometry varies as a function of the specific functional machinery that dominates in a species' metabolism, i.e. cell assembly or resource acquisition. Furthermore, partitioning of phytoplankton-derived organic matter between its dissolved and particulate fractions might be influenced by changes in the nutrient supply (Conan et al., 2007). This response is relevant in respect of DON and DOP as substitute nutrient sources for phytoplankton in waters that are deficient in inorganic nutrient compounds (reviewed by Karl and Björkman, 2002; Bronk et al., 2007).

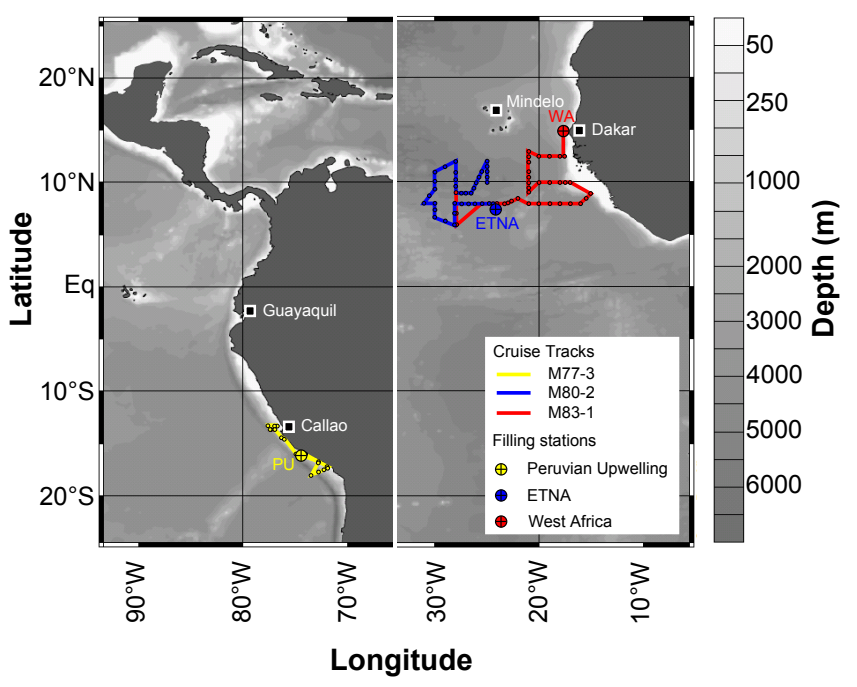

Fig. 1. Map of the tropical Pacific and Atlantic showing filling stations of the mesocosms (crossed circles) plus the following cruise track during the time of experiments (dots) at the respective cruise. Yellow markers denote cruise M77-3 (PU), blue M80-2 (ETNA) and yellow M83-1 (WA).

Our major objective was to test experimentally the response of natural microbial communities taken from the euphotic zone above the OMZs off Peru and Northwest Africa to variable combinations of $\mathrm{N}$ and $\mathrm{P}$ supply concentrations and their ratios. Production of particulate and dissolved organic matter, as well as elemental composition of the bulk microbial community, was determined in order (i) to identify the key nutrient controlling microbial growth, (ii) to unravel whether nutrient $\mathrm{N}: \mathrm{P}$ supply is reflected in the PON : POP composition of accumulated microbial biomass and (iii) to detect potential shifts in the partitioning of accumulated organic matter between dissolved and particulate fractions under different types of nutrient enrichment.

\section{Material and methods}

\subsection{Mesocosm experimental set-up}

This study is based on the results of three nutrient enrichment experiments conducted in shipboard mesocosms during R/V Meteor cruises M77-3 in the Peruvian upwelling (PU) region from Guayaquil (Ecuador) to Callao (Peru) in December/January 2008/09, M80-2 in the ETNA from Mindelo (São Vicente/Cape Verde) to Dakar (Senegal) in November/December 2009 and M83-1 off the coast of West Africa (WA) from Las Palmas (Gran Canaria/Spain) to Mindelo (São Vicente/Cape Verde) in October/November 2010 (Fig. 1).

For each experiment, twelve mesocosms with a volume of $70 \mathrm{~L}$ (PU) or 150 L (ETNA and WA) were distributed over four flow-through gimbal-mounted water baths on deck of 


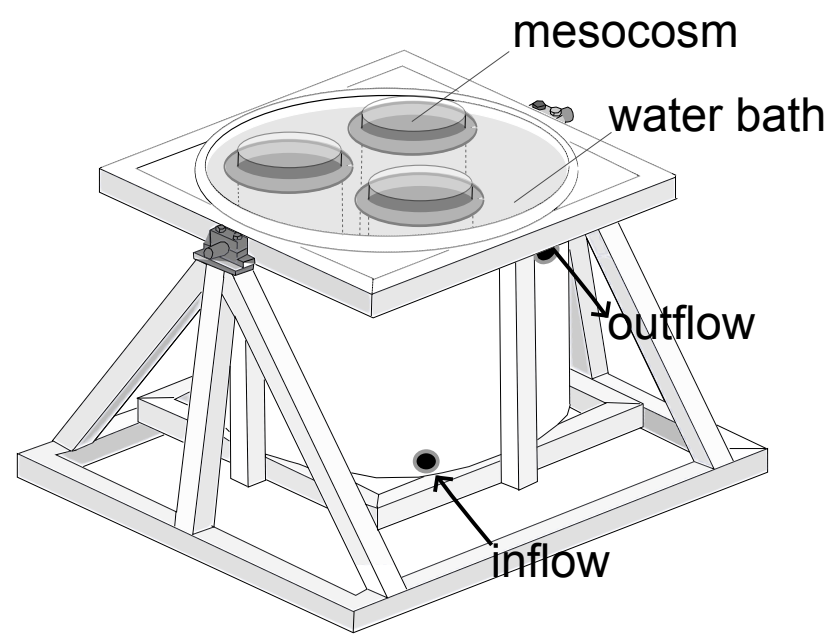

Fig. 2. Schematic draft of three shipboard mesocosms floating in a gimbal-mounted water bath.

the ship (Fig. 2). The single mesocosm enclosure was a cylindrical plastic bag with a plexiglass bottom fixed to a floating tire. On the PU cruise, the mesocosms were filled with $70 \mathrm{~L}$ each, using natural seawater from $10 \mathrm{~m}$ depth (Niskin bottles from CTD-casts), which was pre-screened ( $200 \mu \mathrm{m}$ mesh size) to remove mesozooplankton. On the ETNA cruise, mesocosm bags were each filled with $130 \mathrm{~L}$ of natural seawater from $5 \mathrm{~m}$ water depth using a peristaltic pump. Additionally, a $20 \mathrm{~L}$ inoculum from the chlorophyll $a$ maximum at around $50 \mathrm{~m}$ depth taken with the CTD-rosette was added to each mesocosm. On the WA cruise, mesocosms were each filled completely with $150 \mathrm{~L}$ of seawater from $5 \mathrm{~m}$ depth with the peristaltic pump. As surface mesozooplankton abundance was low at the filling sites during the ETNA and WA cruise, no pre-screening of the medium for mesozooplankton was conducted. Single copepods were removed by hand from the GF/F filters. Continuous flow of ambient surface seawater through the water baths provided in situ temperature conditions $\left(<2{ }^{\circ} \mathrm{C}\right.$ above sea surface temperature $)$ during all three cruises.

Surface irradiance in the mesocosms on the Pacific cruise (700-2600 $\mu \mathrm{mol}$ photons $\mathrm{m}^{-2} \mathrm{~s}^{-1}$ ) was reduced to approximately $30 \%$ by covering the water baths with camouflage nets, whereas solid white lids shaded the tanks on the Atlantic cruises. The solid lids reduced surface light intensity by approximately $50 \%$, resulting in mesocosm light conditions between 100 to $1000 \mu \mathrm{mol}$ photons $\mathrm{m}^{-2} \mathrm{~s}^{-1}$. Initially, inorganic nutrients (ammonium $\left(\mathrm{NH}_{4}^{+}\right)$, nitrite $\left(\mathrm{NO}_{2}^{-}\right)$, nitrate $\left(\mathrm{NO}_{3}^{-}\right)$, phosphate $\left(\mathrm{PO}_{4}^{3-}\right)$, silicate $\left.\left(\mathrm{Si}(\mathrm{OH})_{4}\right)\right)$ of the natural seawater medium were determined and four different $\mathrm{N}: \mathrm{P}$ treatments were adjusted by nutrient additions in each experiment (Table 1). Nutrient concentrations of the initial medium on the PU cruise were increased due to upwelling on the shelf. For adjustment of the four $\mathrm{N}: \mathrm{P}$ treatments, either $\mathrm{N}(+\mathrm{N}), \mathrm{P}(+\mathrm{P}), \mathrm{N}$ combined with $\mathrm{P}(+\mathrm{NP})$ or nothing (con- trol) was added. In contrast, surface nutrient concentrations were extremely low on the West African shelf. To adjust similar nutrient concentrations and $\mathrm{N}: \mathrm{P}$ supply ratios to the $\mathrm{PU}$ experiment, $\mathrm{N}$ and $\mathrm{P}$ were added to all four treatments, but in variable concentrations. Enrichment with high $\mathrm{N}$ and low $\mathrm{P}(+\mathrm{N})$, low $\mathrm{N}$ and high $\mathrm{P}(+\mathrm{P})$, high $\mathrm{N}$ and high $\mathrm{P}(+\mathrm{NP})$, low $\mathrm{N}$ and low $\mathrm{P}$ (control) represented the four treatments. For simplification we use "enrichment", including high addition, or "no enrichment", including low addition, for both experiments.

Initial molar $\mathrm{N}: \mathrm{P}$ supply ratios ranged between 20 and 2.5 in all three experiments. $\mathrm{Si}(\mathrm{OH})_{4}$ and a trace metal mix (Provasoli II trace metal mix; West and McBride, 1999) were added to all treatments (Table 1). Sampling for biogeochemical analyses was conducted on a daily basis for a period of 7 (PU), 9 (ETNA) and 11 days (WA). Because of their smaller volume during the PU cruise, all mesocosms had to be restocked on sampling days 3 and 5 with filtered $(5 \mu \mathrm{m})$ natural surface seawater provided by the internal ship's pump (dilution factors: 0.4 and 0.27 , respectively). Nutrient concentrations of this medium were on average $5.5 \mu \mathrm{mol} \mathrm{L}^{-1}$ DIN, $0.5 \mu \mathrm{mol} \mathrm{L}^{-1} \mathrm{DIP}$ and $8.6 \mu \mathrm{mol} \mathrm{L}^{-1} \mathrm{Si}(\mathrm{OH})_{4}$. Nutrient inventories in the mesocosms were partially restocked through the dilution. Since this was conducted already after the biomass peak and in equal amounts to all twelve mesocosms, we exclude a significant influence on the outcome of the experiment, which was mainly driven by the initial nutrient supply.

\subsection{Inorganic nutrients}

Analysis of the nutrients $\mathrm{NO}_{2}^{-}, \mathrm{NO}_{3}^{-}, \mathrm{PO}_{4}^{3-}$ and $\mathrm{Si}(\mathrm{OH})_{4}$ was conducted on board immediately after sampling according to Hansen and Koroleff (1999). Prior to measurement, samples were pre-filtered through $5 \mu \mathrm{m}$ cellulose acetate filters (26 mm). A Hitachi U-2000 spectrophotometer was used for all colorimetric measurements on the PU cruise, while they were carried out with a QuAAtro AutoAnalyzer (Seal Analytical) during the experiments in the ETNA and WA. $\mathrm{NH}_{4}^{+}$ analysis during PU was conducted according to Holmes et al. (1999), and according to Kerouel and Aminot (1997) with a Jasco FP-2020 fluorometer in the Atlantic.

The utilized abbreviation DIN (dissolved inorganic nitrogen) includes the inorganic nitrogen compounds $\mathrm{NO}_{2}^{-}, \mathrm{NO}_{3}^{-}$ and $\mathrm{NH}_{4}^{+}$; DIP (dissolved inorganic phosphorus) includes $\mathrm{PO}_{4}^{3-}$ and all other forms of orthophosphate.

\subsection{POM}

Water samples from the mesocosms for particulate organic carbon (POC) and nitrogen (PON) and for particulate organic phosphorus (POP) were filtered onto pre-combusted $\left(450{ }^{\circ} \mathrm{C}\right.$ for $5 \mathrm{~h}$ ) Whatman GF/F filters $(0.7 \mu \mathrm{m}$ pore size; $25 \mathrm{~mm}$ diameter) at low vacuum pressure (200 mbar) and stored frozen at $-20^{\circ} \mathrm{C}$ until analysis. Filters for POC/PON were fumed 
Table 1. Overview of mesocosm filling sites, initial and experimental conditions during the three cruises.

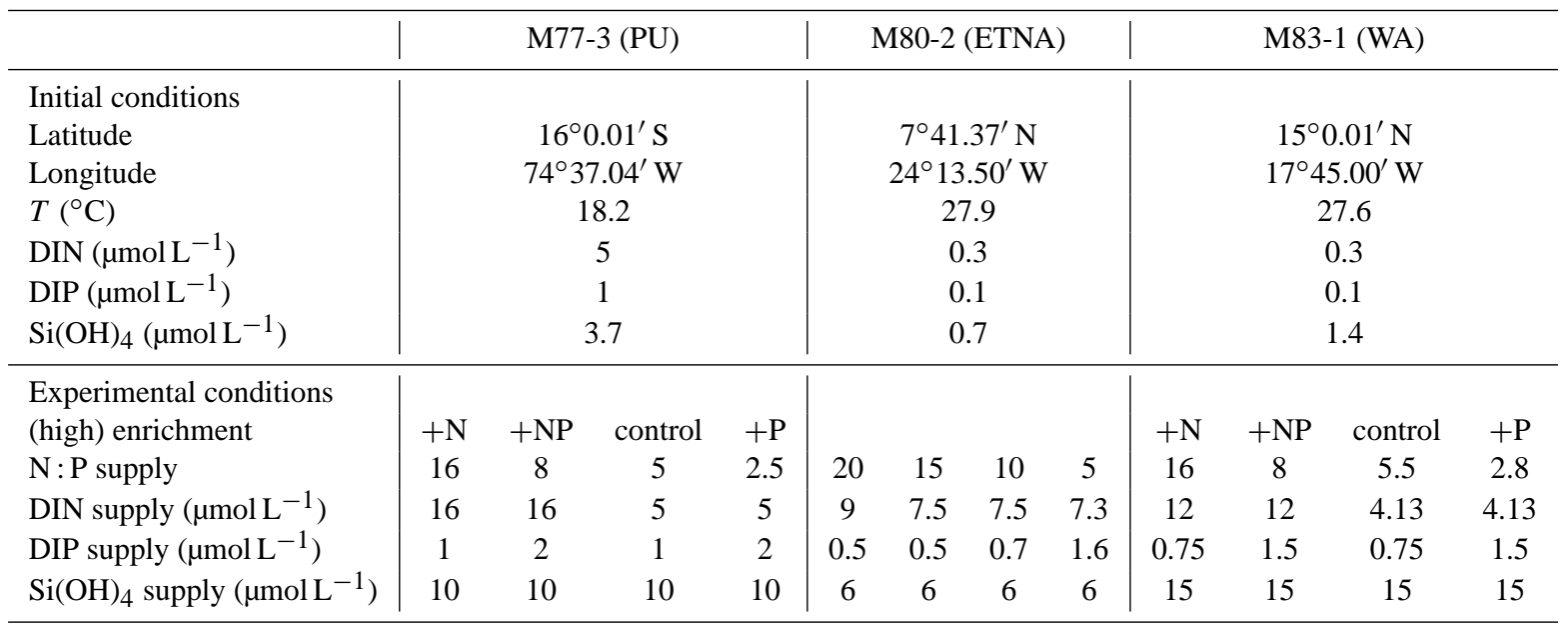

with hydrochloric acid $(37 \%)$ for $\sim 15 \mathrm{~h}$ to remove the inorganic carbon, dried at $60^{\circ} \mathrm{C}$ for $12 \mathrm{~h}$ and wrapped in tin cups $(8 \times 8 \times 15 \mathrm{~mm})$ for combustion. Final measurements of POC and PON were made according to Sharp (1974) using an elemental analyzer (EURO EA Elemental Analyser) coupled to an EUROVECTOR gas chromatograph.

POP was measured using a modified method according to Hansen and Koroleff (1999) by incubating the defrosted filters with the oxidation reagent Oxisolv (Merck) and $40 \mathrm{ml}$ of ultrapure water for $30 \mathrm{~min}$ in a household pressure cooker.

\subsection{DOM}

For the analysis of dissolved organic nitrogen (DON) and phosphorus (DOP), water samples were pre-filtered through combusted $\left(450{ }^{\circ} \mathrm{C}\right.$ for $\left.5 \mathrm{~h}\right)$ Whatman GF/F filters $(25 \mathrm{~mm}$; $0.7 \mu \mathrm{m})$ on the PU and ETNA cruise. No pre-filtration was conducted during the cruise off WA, thus yielding total nitrogen (TN) and phosphorus (TP) instead of total dissolved nitrogen (TDN) and phosphorus (TDP), respectively.

Analysis was accomplished according to Koroleff (1977). Initially, one portioning spoon of the oxidation reagent Oxisolv (Merck) was dissolved in $40 \mathrm{ml}$ of sample and autoclaved in a pressure cooker for $30 \mathrm{~min} .10 \mathrm{ml}$ of the oxidized sample were added to $0.3 \mathrm{ml}$ of a mixed reagent $(4.5 \mathrm{M}$ $\mathrm{H}_{2} \mathrm{SO}_{4}^{+} \mathrm{NH}_{4}^{+}$- molybdate + potassium antimonyl tartrate) and $0.3 \mathrm{ml}$ of ascorbic acid, incubated for $10 \mathrm{~min}$, and finally TDP (PU, ETNA) or TP (WA) was determined colorimetrically at $882 \mathrm{~nm}$ against ultrapure water. Detection limit of the method was $0.2 \mu \mathrm{mol} \mathrm{L}-1$, and analytical precision was $\pm 8.3 \%$. The DOP concentration was calculated as follows:

$\mathrm{DOP}=\mathrm{TDP}-\mathrm{DIP} ;$

$\mathrm{DOP}=\mathrm{TP}-(\mathrm{DIP}+\mathrm{POP})$.

DON was analyzed by pumping the oxidized sample through a cadmium-containing reductor, resulting in the re- duction of all dissolved organic nitrogen compounds to $\mathrm{NO}_{2}^{-}$. After an incubation of $30 \mathrm{~min}$, TDN (PU, ETNA) or TN (WA) was measured with a spectrophotometer at a wavelength of $542 \mathrm{~nm}$ against ultrapure water. Detection limit of the method was $0.1 \mu \mathrm{mol} \mathrm{L}^{-1}$, and analytical precision was $\pm 0.1 \mu \mathrm{mol} \mathrm{L}{ }^{-1}$. The DON concentration was obtained as follows:

$\mathrm{DON}=\mathrm{TDN}-\mathrm{DIN} ;$

$\mathrm{DON}=\mathrm{TN}-(\mathrm{DIN}+\mathrm{PON})$.

Measurement of TDN from the WA experiment was carried out in combination with the DOC analysis (PU and WA). Water samples for TDN and DOC were collected in ultraclean and pre-combusted $\left(450^{\circ} \mathrm{C}\right.$ for $\left.12 \mathrm{~h}\right)$ glass vials and stored at $-20^{\circ} \mathrm{C}$. In a solvent-free clean laboratory on land, thawed samples were filtrated through combusted $\left(450^{\circ} \mathrm{C}\right.$ for $6 \mathrm{~h}) \mathrm{GF} / \mathrm{F}$ filters and acidified by adding $20 \mu \mathrm{L} \mathrm{HCl}$ (32\%) to each sample. Analysis of TDN (detection limit: $2 \mu \mathrm{mol} \mathrm{L}{ }^{-1}$; AP: $\pm 1 \mu \mathrm{mol} \mathrm{L}^{-1}$ ) and DOC (DL: $5 \mu \mathrm{mol} \mathrm{L}-1$; AP: $\left.\pm 1 \mu \mathrm{mol} \mathrm{L}^{-1}\right)$ was conducted using the HTCO method (high-temperature catalytic oxidation) (Wurl and Min Sin, 2009) on a Shimadzu TOC-V analyzer. The accuracy of the analysis was validated several times a day with deep-sea reference material provided by the University of Miami. Concentrations of DON were calculated using Eq. (3).

\subsection{Flow cytometry (FCM)}

Cell counts for bacterial abundance were obtained using a flow cytometer (FACScalibur, Becton Dickinson, San Jose, CA, USA). Samples $(5 \mathrm{ml})$ were fixed with $2 \%$ formaldehyde and frozen at $-80^{\circ} \mathrm{C}$. Prior to measurement at a flow rate of $13.9 \mu \mathrm{min}^{-1}$, samples were diluted $1: 3$ and stained with SYBR-Green. 


\subsection{Phytoplankton marker pigments}

Samples for phytoplankton pigment analysis via HPLC (High Pressure Liquid Chromatography) were vacuumfiltered onto Whatman $\mathrm{GF} / \mathrm{F}$ filters $(0.7 \mu \mathrm{m}$ pore size; $25 \mathrm{~mm}$ diameter) at low pressure $(200 \mathrm{mbar})$ and immediately stored frozen at $-80^{\circ} \mathrm{C}$. For pigment extraction, each filter was covered with approximately $3 \mathrm{~g}$ of glass beads $(2 \mathrm{~mm}+4 \mathrm{~mm})$ and $2 \mathrm{ml}$ of acetone and homogenized in a cell mill (Edmund Bühler $\mathrm{GmbH}$ ) for $5 \mathrm{~min}$. After centrifugation for $10 \mathrm{~min}$ at $5000 \mathrm{rpm}$, the supernatant was filtered through a $0.2 \mu \mathrm{m}$ Teflon filter and the extract stored at $-80^{\circ} \mathrm{C}$. The HPLC measurement was conducted by a Waters 600 controller in combination with a Waters 996 photodiode array detector (PDA) and a Waters 717plus Autosampler according to the modified method after Barlow et al. (1997). Classification and quantification of the phytoplankton pigments was carried out using the software EMPOWERS (Waters GmbH, Eschborn, Germany). Phytoplankton class abundances were calculated using the matrix factorizing program CHEMTAX (Mackey et al., 1997), which aims at estimating the contributions of individual phytoplankton groups to the microalgal community based on the detected concentrations of marker pigments and the theoretical ratios of individual pigments to chlorophyll $a(\mathrm{Chl} a$ ) for each taxonomic class. The applied pigment ratios are representative for species of the tropical/equatorial ocean (Mackey et al., 1996).

\subsection{Microplankton counts}

During the PU experiment, Lugol-stained microplankton were counted daily on board using an inverted microscope according to Utermöhl (1958). The biovolume was calculated after approximation to geometric shapes (Hillebrand et al., 1999) and converted to biomass $\left(\mu \mathrm{g} \mathrm{CL}^{-1}\right)$ using the carbon to volume relationships from Menden-Deuer and Lessard (2000).

\subsection{Calculations}

Build-up of dissolved and particulate organic matter in the three experiments was determined based on the time period of exponential growth from the initial sampling day until the first day after nutrient exhaustion. The first day after complete DIN exhaustion in all treatments plus the subsequent day (in order to compensate temporal fluctuation of individual maxima of organic matter) was defined for each experiment as the time of maximum organic matter accumulation (PU: day 4 and 5; ETNA: day 6 and 7; WA: day 4 and 5). The difference in concentration between the initial sampling day and the respective day of maximum accumulation represented the build-up of organic matter. It was not possible to calculate a build-up of DOP during the WA experiment as measured concentrations were in large part close to or even below the detection limit of $0.2 \mu \mathrm{mol} \mathrm{L}^{-1}$ throughout the experiment, and the associated large daily variability in the data precluded a determination of accumulating DOP for each treatment.

Drawdown of nutrients was determined in accordance with the accumulation of organic matter (i.e. it was defined as the difference in DIN or DIP respectively) from initial sampling until the maximum of organic matter accumulation (PU: day 4 and 5; ETNA: day 6 and 7; WA: day 4 and 5). To highlight differences in nutrient drawdown at variable $\mathrm{N}: \mathrm{P}$ supply, treatments were united into four $\mathrm{N}: \mathrm{P}$ supply groups: $\sim 16: 1$ (including $\mathrm{N}: \mathrm{P}$ treatments of $15: 1$ and $16: 1$ ), $\sim 8: 1$ (including $\mathrm{N}: \mathrm{P}$ treatments of $8: 1$ and $10: 1$ ), $\sim 5: 1$ (including $\mathrm{N}: \mathrm{P}$ treatments of $5: 1$ and $5.5: 1$ ), and $\sim 2: 1$ (including $\mathrm{N}: \mathrm{P}$ treatments of $2.5: 1$ and $2.8: 1$ ).

Effects of nutrient enrichment on production of POM and DOM compounds were identified using the effect size metric response ratio $\mathrm{RR}_{x}$, calculated as follows:

$\mathrm{RR}_{x}=\ln (E / C)$,

where $E$ denotes the build-up of the respective organic compound in the enriched treatment $(+\mathrm{N},+\mathrm{P}$ or $+\mathrm{NP})$, whereas $C$ represents the build-up of the variable in the control (see Table 1). Since it was impossible to determine an accumulation of DOP during the WA cruise, absolute concentrations of DOP were used for calculating $\mathrm{RR}_{x}$.

\subsection{Statistical analyses}

Relationships of pelagic community response variables to the inorganic $\mathrm{N}$ : $\mathrm{P}$ supply ratio and drawdown ratios of DIN and DIP were determined using regression analyses (SigmaPlot, Systat). Effects of the three nutrient enrichment treatments $(+\mathrm{N},+\mathrm{P}$, or $+\mathrm{NP})$ on $\mathrm{RR}_{x}$ of the accumulated dissolved and particulate organic compounds during the experiments in the PU and off WA were compared using one-way ANOVA, followed by Tukey's post-hoc test to compare specific combinations of factors (Statistica 8, StatSoft). A significance level of $p<0.05$ was applied to all statistical tests.

\section{Results}

\subsection{Nutrient uptake}

Removal of DIN and DIP per biomass unit from the medium was closely related to the $\mathrm{N}$ : $\mathrm{P}$ supply ratio over all three experiments (Fig. 3). Drawdown ratios determined through the regression slopes of DIN versus DIP reflected the $\mathrm{N}: \mathrm{P}$ supply. $\mathrm{N}: \mathrm{P}$ drawdown in the $\sim 16: 1 \mathrm{~N}: \mathrm{P}$ treatments was $17.18( \pm 0.49), 8.42( \pm 0.30)$ in the $\sim 8: 1$ treatments, $6.21( \pm 0.48)$ in the $\sim 5: 1$ treatments and $2.93( \pm 3.21)$ in the treatments with an $\mathrm{N}: \mathrm{P}$ supply of about $2: 1$. 
Table 2. Summary of $p$-values obtained from ANOVA comparing the effects of the three high nutrient enrichment treatments $(+\mathrm{N},+\mathrm{P}$, or $+\mathrm{NP}$ ) on build-up (POC, PON, POP, DOC, DON) or concentration (DOP) of organic elemental compounds during the PU and WA experiment. Statistically significant effects $(p<0.05)$ are denoted in bold.

\begin{tabular}{llrrrr}
\hline Experiment & Factor & $+\mathrm{N}$ vs. $+\mathrm{P}$ & $+\mathrm{N}$ vs. $+\mathrm{NP}$ & $+\mathrm{P}$ vs. $+\mathrm{NP}$ & Treatment \\
\hline $\mathrm{PU}$ & $\mathrm{RR}_{x}[\mathrm{POC}]$ & 0.134 & 0.975 & 0.193 & 0.106 \\
& $\mathrm{RR}_{x}[\mathrm{PON}]$ & 0.162 & 0.987 & 0.210 & 0.120 \\
& $\mathrm{RR}_{x}[\mathrm{POP}]$ & 0.998 & 0.314 & 0.277 & 0.243 \\
& $\mathrm{RR}_{x}[\mathrm{DOC}]$ & 0.652 & 0.996 & 0.665 & 0.577 \\
& $\mathrm{RR}_{x}[\mathrm{DON}]$ & 0.629 & 0.886 & 0.908 & 0.654 \\
& $\mathrm{RR}_{x}[\mathrm{DOP}]$ & 0.225 & $\mathbf{0 . 0 3 9}$ & 0.398 & $\mathbf{0 . 0 4 7}$ \\
\hline $\mathrm{WA}$ & $\mathrm{RR}_{x}[\mathrm{POC}]$ & $\mathbf{0 . 0 0 1}$ & 0.994 & $\mathbf{0 . 0 0 2}$ & $\mathbf{0 . 0 0 0 5}$ \\
& $\mathrm{RR}_{x}[\mathrm{PON}]$ & $\mathbf{0 . 0 0 0 2}$ & 0.473 & $\mathbf{0 . 0 0 0 5}$ & $<\mathbf{0 . 0 0 0 1}$ \\
& $\mathrm{RR}_{x}[\mathrm{POP}]$ & 0.993 & 0.054 & 0.066 & $\mathbf{0 . 0 3 6}$ \\
& $\mathrm{RR}_{x}[\mathrm{DOC}]$ & $\mathbf{0 . 0 0 6}$ & $\mathbf{0 . 0 0 0 9}$ & $\mathbf{0 . 0 0 0 2}$ & $<\mathbf{0 . 0 0 0 1}$ \\
& $\mathrm{RR}_{x}[\mathrm{DON}]$ & 0.188 & 0.804 & 0.464 & 0.205 \\
& $\mathrm{RR}_{x}[\mathrm{DOP}]$ & 0.621 & 0.321 & 0.065 & 0.074 \\
\hline
\end{tabular}

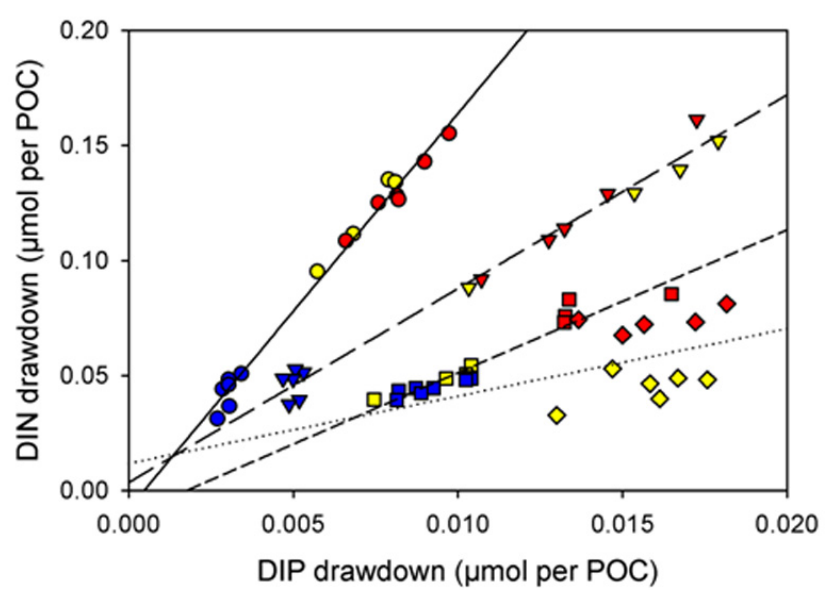

Fig. 3. Drawdown of DIN versus DIP (both normalized to per POC unit) during the PU (yellow), ETNA (blue) and WA (red) experiments. Linear regressions were fitted to the nutrient drawdown in the treatments supplied with $\mathrm{N}: \mathrm{P} \sim 16: 1$ (circles; straight line: $y=17.18( \pm 0.49) x-0.01( \pm 0.003), r^{2}=$ $0.989, \quad p<0.0001), \mathrm{N}: \mathrm{P} \sim 8: 1$ (triangles; long-dashed line: $\left.y=8.42( \pm 0.30) x+0.004( \pm 0.004), r^{2}=0.984, \quad p<0.0001\right)$, $\mathrm{N}: \mathrm{P} \sim 5: 1 \quad$ (squares; short-dashed line: $y=6.21( \pm 0.48) x-$ $\left.0.01( \pm 0.01), r^{2}=0.923, p<0.0001\right)$ and $\mathrm{N}: \mathrm{P} \sim 2: 1$ (diamonds; dotted line: $y=2.93( \pm 3.21) x+0.01( \pm 0.05), r^{2}=0.085, p=$ 0.386).

\subsection{Nutrient enrichment and build-up of organic matter}

Our data show that the microbial community was limited by $\mathrm{N}$ within the PU and WA experiments. This effect was noticeably stronger in the experiment carried out in the Atlantic (WA) (Fig. 4; Table 2). $\mathrm{N}$ addition induced strong responses of POC and PON build-up compared to the P enriched treatment, whether through fertilization by $\mathrm{N}$ alone
$\left(p_{\mathrm{POC}}=0.001 ; p_{\mathrm{PON}}=0.002\right)$ or in combination with $\mathrm{P}$ $\left(p_{\mathrm{POC}}=0.002 ; p_{\mathrm{PON}}=0.001\right)($ Fig. $4 \mathrm{a}$ and $\mathrm{b})$.

$\mathrm{P}$ supply provoked only a minor increase in the response of POC production relative to the control treatment, and PON build-up was even negatively affected by $\mathrm{P}$ supply. The same trend was observed for the mesocosm experiment in the PU, but effects were not significant due to large standard deviations within the three treatments.

In both experiments, combined supply of $\mathrm{N}$ and $\mathrm{P}$ generated increased accumulation of POP compared to addition of N (PU: $p=0.314$; WA: $p=0.054$ ) or P (PU: $p=0.277$; WA: $p=0.066$ ) alone (Fig. 4c).

DOC and DON production displayed no statistically significant difference in the $\mathrm{RR}_{x}$ between the three treatments during the PU cruise ( $p=0.577$ ) (Fig. $4 d$ and e). In the WA experiment, build-up of DOC and DON responded in a similar way to $\mathrm{N}$ fertilization like POC and PON, although the response for DOC in the +NP treatment was two-fold increased compared to the $\mathrm{RR}_{x}$ in the $+\mathrm{N}$ treatment ( $p=0.001)$. Nonetheless, $\mathrm{N}$ enrichment caused a significantly elevated DOC accumulation in contrast to $\mathrm{P}$ supply $(+\mathrm{N}: p=0.006$; $+\mathrm{NP}: p=0.0002)$. DON production appeared to be also promoted by $\mathrm{N}$ supply, but no significant effect between the three treatments could be detected due to high variability among replicates and sampling days $(p=0.205)$.

Absolute concentrations of DOP were used to assess the effect of nutrient enrichment on DOP, since no detectable accumulation of DOP occurred within the WA experiment. The variation of DOP within the treatments caused strong negative responses to single high $\mathrm{N}$ or $\mathrm{P}$ supply and positive $\mathrm{RR}_{x}$ in the +NP mesocosms (Fig. 4f). The measured fluctuation of DOP stocks around the detection limit of $0.2 \mu \mathrm{mol} \mathrm{L}-1$ suggests a high uncertainty in DOP data. In the experiment off Peru, DOP was affected by high $\mathrm{P}$ addition, as $\mathrm{RR}_{x}$ 

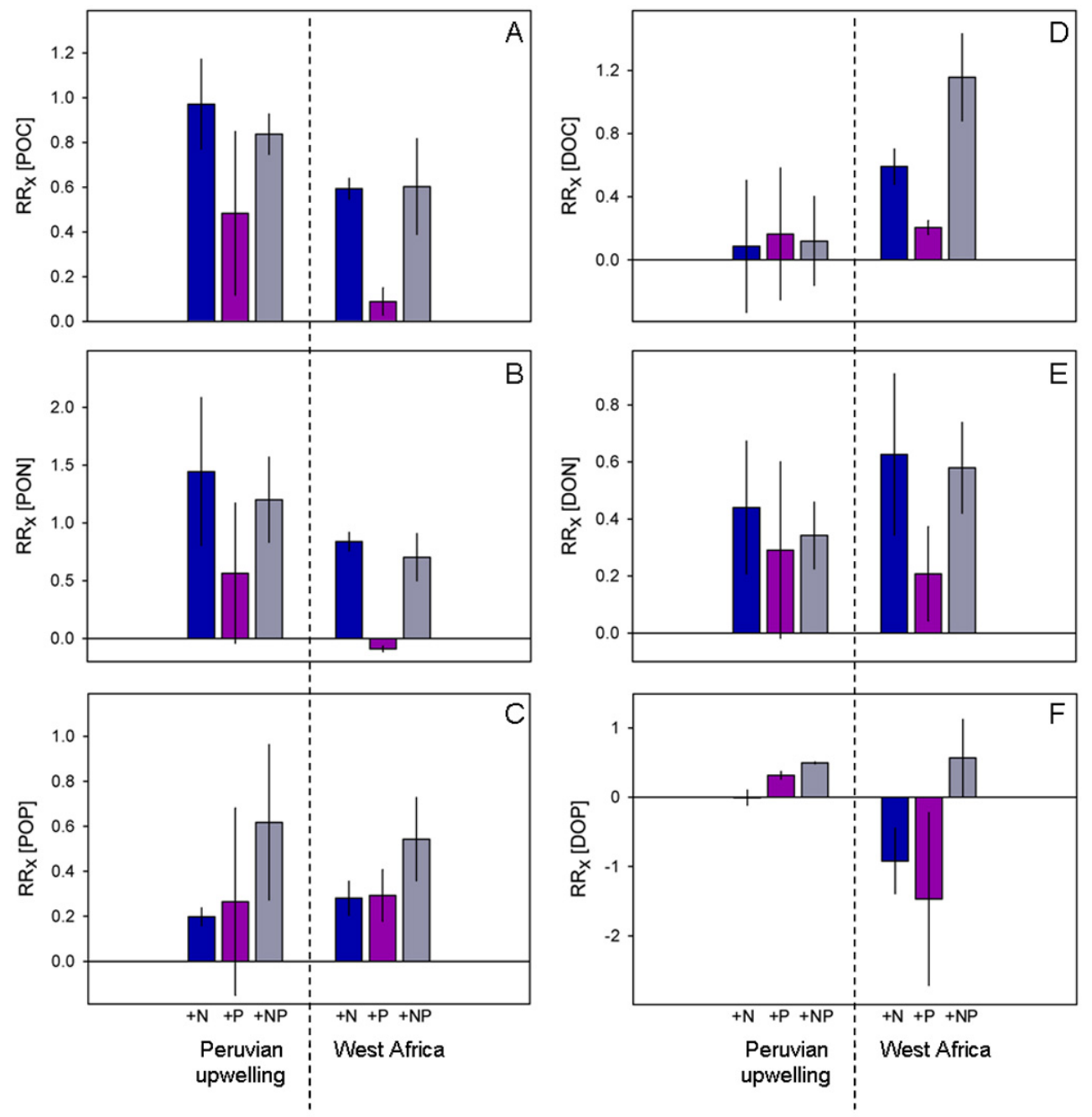

Fig. 4. Relative responses $\left(R_{x}\right)$ of the microbial communities to enrichment in high $\mathrm{N}(+\mathrm{N}$, blue), high $\mathrm{P}(+\mathrm{P}$, purple) or to combined high $\mathrm{N}$ and high $\mathrm{P}(+\mathrm{NP}$, grey), during the PU (Peruvian upwelling) and the WA (West Africa) experiments. Response variables are build-up of (A) POC, (B) PON, (C) POP, (D) DOC and (E) DON. (F) Since no accumulation of DOP could be determined for the WA experiment, absolute concentrations of DOP were used to evaluate $\mathrm{RR}_{x}$. For detailed calculation of $\mathrm{RR}_{x}$, see Sect. 2.8. Values are treatment means and the error bars denote the standard deviation for two consecutive days of production within each treatment of high nutrient enrichment.

was increased in the $+\mathrm{P}$ and $+\mathrm{NP}$ treatment, whereas $\mathrm{DOP}$ showed on average no response to $\mathrm{N}$ fertilization. In particular the combined addition of $\mathrm{N}$ and $\mathrm{P}$ resulted in increased concentrations of DOP in relation to the $+\mathrm{N}$ treatment $(p=0.039)$.

\subsection{Microbial community structure}

Accounting for approximately $40-60 \%$ of total Chl $a$, diatoms represented the dominating photoautotrophic group during all three experiments (Fig. 5). Comprising four different taxa (chrysophytes, haptophytes, dinoflagellates and cryptophytes), the large group of flagellates was a further significant contributor to microalgal biomass. During the ETNA experiment, flagellate phytoplankton accounted on average for about $36 \%$ of the algal community in all four $\mathrm{N}: \mathrm{P}$ treatments and for between 20-30\% during the PU cruise. Flagellate biomass was lowest off WA $(\sim 15 \%)$ compared to the other four defined microalgal groups. Chlorophytes played a minor role in the phytoplankton assemblage during the PU and WA trials ( $\sim 4-7 \%$ of total Chl $a$ ). However, they represented after diatoms and flagellates the third-largest contributor of photoautotrophic biomass in the ETNA with a percentage of $\sim 11-17 \%$. The relative content of nitrogen $\left(\mathrm{N}_{2}\right)$ fixing cyanobacteria was very low within that same experiment $(\sim 4 \%)$, while they accounted for between $16-25 \%$ of microalgal biomass during PU and WA. In fact, percentage of bulk Chl $a$ during these two experiments was larger in the two high treatments of $\mathrm{N}: \mathrm{P}$ supply compared to the two lower N:P treatments. Biomass of picocyanobacteria 


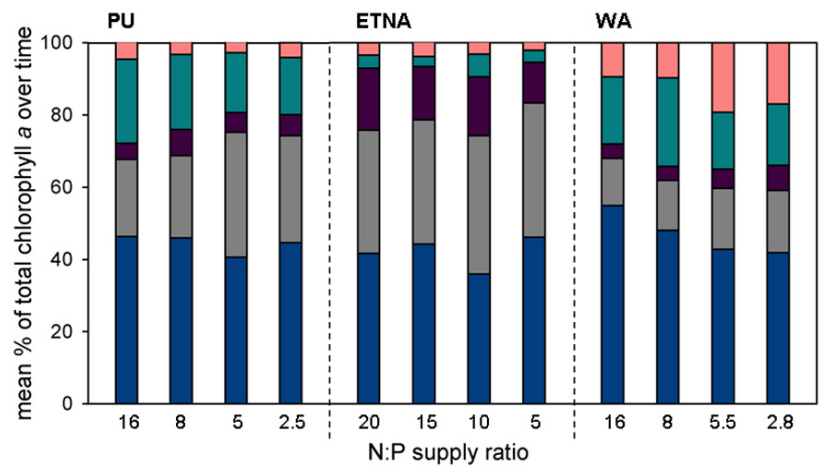

Fig. 5. Mean composition of the phytoplankton community for each $\mathrm{N}: \mathrm{P}$ supply treatment over the entire duration of the respective experiment based on the contribution of each phytoplankton group to total chlorophyll $a$. Five taxonomic groups of microalgae are defined: diatoms (blue), flagellates (grey; including chrysophytes, haptophytes, dinoflagellates and crytophytes), chlorophytes (dark purple; including chlorophytes and prasinophytes), N-fixing cyanobacteria (green), picocyanobacteria (pink; including Synechococcus).

(Synechococcus) was negligible during PU and ETNA, based on their low Chl $a$ contribution of $\sim 3 \%$. The situation was different in the experiment off WA, where picocyanobacteria accounted for $10 \%$ of total Chl $a$ under higher N : P supply (16:1 and $8: 1$ ), and up to $20 \%$ under low $\mathrm{N}: \mathrm{P}$ of $5.5: 1$ and $2.8: 1$, respectively.

The microbial community in the mesocosm experiments consisted beside of phytoplankton also of bacteria and microzooplankton (mainly ciliates). Their mean contribution to the organic carbon pool for the respective $\mathrm{N}: \mathrm{P}$ treatment over the complete duration of each experiment is summarized in Table 3. Ciliates accounted for $\sim 5 \%$ of the organic carbon during the PU trial. No data of ciliate abundance are available for ETNA and WA. Bacteria of the size range $<0.7 \mu \mathrm{m}$ provided on average $\sim 8 \%(\mathrm{PU}), \sim 16 \%$ (ETNA) or $\sim 23 \%$ of organic carbon, respectively.

\subsection{Elemental stoichiometry of particulate organic matter}

Over all three mesocosm experiments, the PON : POP ratio of biomass build-up correlated positively with the inorganic $\mathrm{N}$ : $\mathrm{P}$ supply ratio $(p<0.0001)$ (Fig. 6). Thus, the supplied $\mathrm{N}: \mathrm{P}$ stoichiometry did influence the PON : POP production ratio of the microbial community, although the PON:POP of produced biomass exceeded the $\mathrm{N}$ : $\mathrm{P}$ of nutrient supply in most cases. This deviation between the inorganic and organic $\mathrm{N}: \mathrm{P}$ ratio slightly increased with decreasing supply ratios, denoted by the slope of linear regression of $0.90( \pm 0.07)$. No PON : POP values lower than $5: 1$ were observed, although some treatments were provided with even lower nutrient $\mathrm{N}: \mathrm{P}$ ratios of 2.8 and 2.5 .

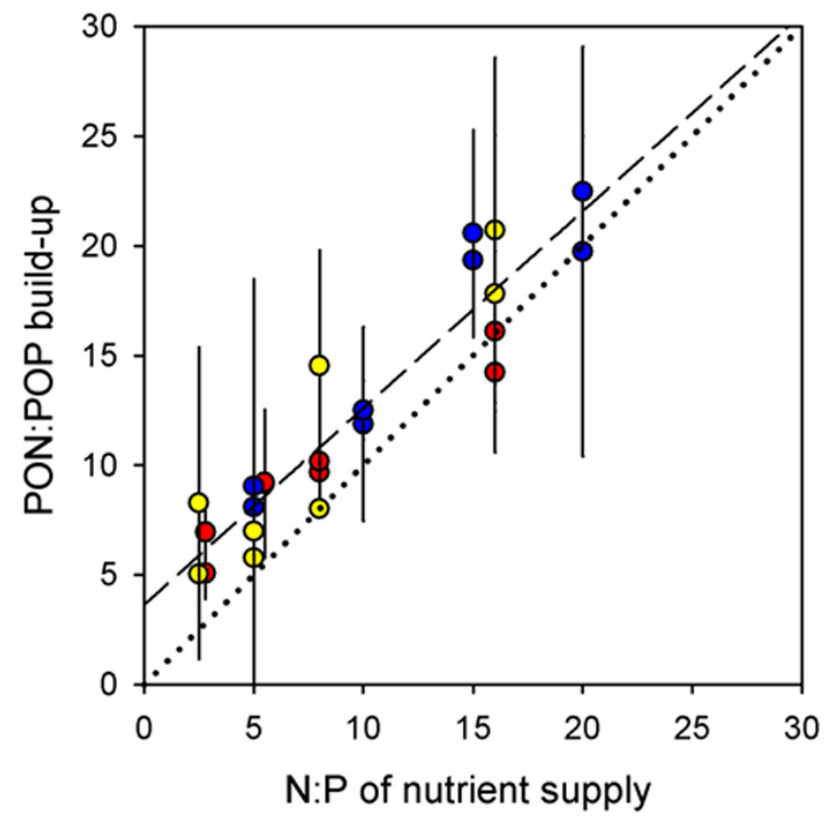

Fig. 6. Positive linear correlation (dashed line: $y=$ $\left.0.90( \pm 0.07) x+3.64( \pm 0.08), \quad r^{2}=0.875, \quad p<0.0001\right) \quad$ between N:P of nutrient supply and the PON: POP of produced biomass until day one and two after DIN limitation in the PU (yellow), ETNA (blue) and WA (red) experiment. Dotted line indicates PON : POP build-up equal to N:P supply. Values are treatment means and the vertical error bars denote the standard deviation of replicates within each $\mathrm{N}: \mathrm{P}$ treatment.

During exponential growth under nutrient-saturated conditions, PON : POP across all experiments fluctuated between a range of $11: 1$ to $21: 1$, regardless of the respective $\mathrm{N}: \mathrm{P}$ supply ratio (Fig. 7a). PON : POP composition within the individual experiments only slightly varied between the treatments. When phytoplankton entered the stationary growth phase due to exhaustion of $\mathrm{N}$, their PON : POP began to diverge between the treatments and towards their respective $\mathrm{N}: \mathrm{P}$ supply ratio (Fig. $7 \mathrm{~b}$ ). $\mathrm{N}: \mathrm{P}$ supply conditions $<16$ : 1 , indicating $\mathrm{N}$-limitation of the microbial community according to Redfield, caused in general a decrease in the PON : POP. Redfield- or P-limited conditions, induced by an initial $\mathrm{N}: \mathrm{P} \geq 16: 1$, entailed an increase of the microbial $\mathrm{N}: \mathrm{P}$ stoichiometry. These effects were strong in the ETNA and WA experiments, and more weakly pronounced in the PU approach. Overall, PON : POP composition of the microbial assemblage ranged between $6: 1$ to $24: 1$ over all experiments during the stationary phase.

The relation between nutrient uptake and the production of biomass is demonstrated in Table 4. In general, initial inventories of $\mathrm{N}$ and $\mathrm{P}$ were consumed completely and $\mathrm{N}: \mathrm{P}$ uptake closely matched the $\mathrm{N}: \mathrm{P}$ supply in all experiments. But the uptake ratio of $\mathrm{N}: \mathrm{P}$ exceeded the supply ratio in the lowest $\mathrm{N}: \mathrm{P}$ treatments of the PU $(2.5: 1)$ and the WA $(2.8: 1)$ trial, as unused $P$ was left in the medium during both 
Table 3. Mean contribution of heterotrophic bacteria $(<0.7 \mu \mathrm{m})$ and microzooplankton (ciliates) to the organic carbon pool over time for each of the three experiments. No data of microzooplankton are available for the ETNA and WA experiment.

\begin{tabular}{lrcc}
\hline & $\begin{array}{r}\text { N:P } \\
\text { supply }\end{array}$ & $\begin{array}{c}\text { mean carbon contribution } \\
\text { of bacteria }<0.7 \mu \mathrm{m} \\
( \pm \mathrm{SD})(\%)\end{array}$ & $\begin{array}{c}\text { mean carbon contribution of } \\
\text { microzooplankton } \\
( \pm \text { SD })(\%)\end{array}$ \\
\hline PU & 16 & $7.6( \pm 3.6)$ & $3.3( \pm 1.6)$ \\
& 8 & $7.9( \pm 3.1)$ & $3.4( \pm 1.3)$ \\
& 5 & $8.4( \pm 2.7)$ & $6.3( \pm 5.2)$ \\
& 2.5 & $7.9( \pm 3.3)$ & $5.3( \pm 2.9)$ \\
\hline ETNA & 20 & $18.6( \pm 25.0)$ & $\mathrm{n} / \mathrm{a}$ \\
& 15 & $15.8( \pm 18.6)$ & $\mathrm{n} / \mathrm{a}$ \\
& 10 & $15.2( \pm 19.4)$ & $\mathrm{n} / \mathrm{a}$ \\
& 5 & $13.1( \pm 14.7)$ & $\mathrm{n} / \mathrm{a}$ \\
\hline WA & 16 & $21.2( \pm 7.5)$ & $\mathrm{n} / \mathrm{a}$ \\
& 8 & $24.4( \pm 7.5)$ & $\mathrm{n} / \mathrm{a}$ \\
& 5.5 & $21.8( \pm 7.1)$ & $\mathrm{n} / \mathrm{a}$ \\
& 2.8 & $23.2( \pm 6.5)$ & $\mathrm{n} / \mathrm{a}$ \\
\hline
\end{tabular}

experiments (data not shown). Values $<1$ of the quotient of $\mathrm{N}$ : $\mathrm{P}$ uptake and build-up display that PON : POP production was, with a few exceptions, higher than $\mathrm{N}$ : P drawdown. This discrepancy in the ratio of nutrient consumption and particulate matter production increased in each experiment with decreasing $\mathrm{N}$ : $\mathrm{P}$ supply and is therefore congruent to the offset between PON: POP build-up and the $\mathrm{N}$ : $\mathrm{P}$ supply ratio shown in Fig. 6.

\subsection{Partitioning of organic matter}

Changes occurred in the partitioning of $\mathrm{N}$ - and P-containing organic matter between the dissolved and the particulate fraction in relation to nutrient supply. Build-up of PON decreased with decreasing $\mathrm{N}: \mathrm{P}$ supply in the PU (slope of regression $(\mathrm{SR})=0.46( \pm 0.19), p=0.053)$ and WA $(\mathrm{SR}=0.50( \pm 0.11), p=0.005)$ trial, whereas PON accumulation was unaffected by nutrient supply in the ETNA experiment $(\mathrm{SR}=0.07( \pm 0.04), p=0.094)$ (Fig. 8a; Table 5). DON production showed no significant response to the $\mathrm{N}: \mathrm{P}$ supply ratio in the ETNA $(\mathrm{SR}=0.03( \pm 0.05)$, $p=0.625)$ and the PU experiment $(\mathrm{SR}=0.20( \pm 0.12)$, $p=0.129$ ) (Fig. 8b). Like PON, DON build-up was also significantly reduced with lower $\mathrm{N}: \mathrm{P}$ supply off West Africa $(\mathrm{SR}=0.19( \pm 0.07), p=0.040)$. The nutrient $\mathrm{N}: \mathrm{P}$ stoichiometry did not have an effect on POP production in the PU $(\mathrm{SR}=0.002( \pm 0.012), p=0.897)$ and WA trial $(\mathrm{SR}=0.004( \pm 0.013), p=0.771)$, while POP accumulation was significantly higher at low $\mathrm{N}: \mathrm{P}$ supply in the ETNA trial ( $\mathrm{SR}=0.033$ (0.009), $p=0.011$ ) (Fig. 8c). Build-up of DOP was stimulated by lowered $\mathrm{N}$ : P supply off Peru (SR = $-0.012( \pm 0.014), p=0.411)$ and in the ETNA experiment $(\mathrm{SR}=-0.020( \pm 0.007), p=0.020)$ (Fig. 8d). The influence of the nutrient $\mathrm{N}: \mathrm{P}$ stoichiometry on DOP production

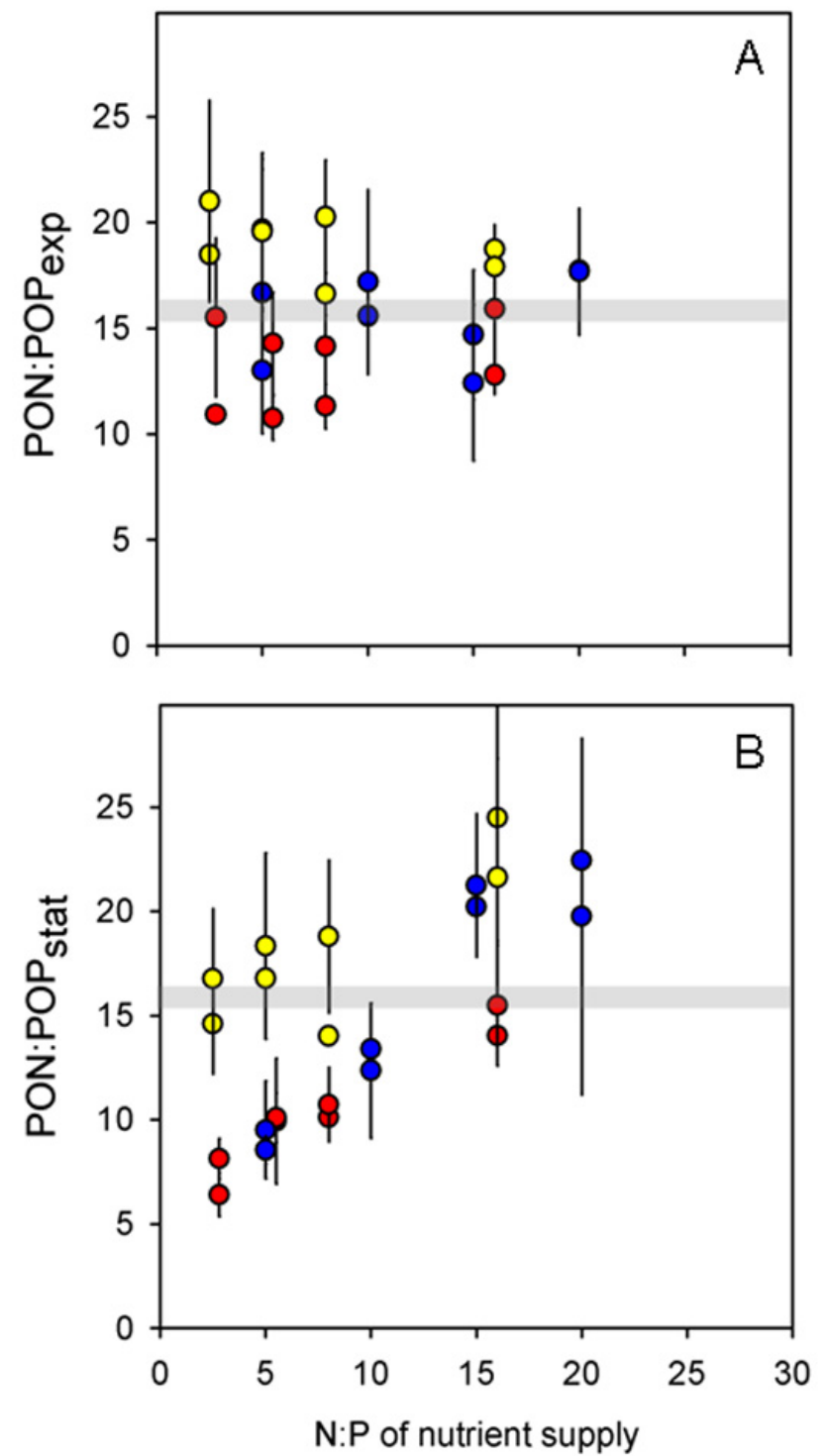

Fig. 7. $\mathrm{PON}$ : POP stoichiometry during (A) exponential and (B) stationary growth phase. Greyish bars signify the $\mathrm{N}$ : P Redfield ratio of $16: 1$. Style and colour-coding according to Fig. 6 .

in the WA experiment could not be determined, since DOP did not accumulate in this experiment.

\section{Discussion}

\subsection{Nutrient limitation of microbial community}

In the mesocosm experiments conducted in the upwelling areas off Peru (PU) and Northwest Africa (WA), the microbial assemblage responded with enhanced growth to the addition of $\mathrm{N}$, while combined fertilization of $\mathrm{N}$ and $\mathrm{P}$ did not induce a further increase in biomass production compared to $\mathrm{N}$-alone enrichment (Fig. 4). The effect that $\mathrm{N}$ was the critical element 
Table 4. Summary of the N : P uptake and the stoichiometry of particulate organic matter build-up within each experiment. The quotient of $\mathrm{N}$ : P drawdown and PON : POP build-up describes the analogy of N : P uptake and produced PON : POP.

\begin{tabular}{lrccc}
\hline & $\begin{array}{r}\mathrm{N}: \mathrm{P} \\
\text { supply }\end{array}$ & $\begin{array}{c}\mathrm{N}: \mathrm{P} \text { drawdown } \\
( \pm \mathrm{SD})\left(\mu \mathrm{mol} \mathrm{L} \mathrm{L}^{-1}\right)\end{array}$ & $\begin{array}{c}\text { PON : POP build-up } \\
\left.( \pm \mathrm{SD})(\mu \mathrm{mol} \mathrm{L})^{-1}\right)\end{array}$ & $\begin{array}{c}\mathrm{N}: \text { P drawdown/ } \\
\text { PON : POP build-up }\end{array}$ \\
\hline PU & 16 & $17.0( \pm 0.3)$ & $19.3( \pm 6.4)$ & 0.88 \\
& 8 & $8.8( \pm 0.4)$ & $11.3( \pm 4.9)$ & 0.78 \\
& 5 & $5.7( \pm 0.8)$ & $8.8( \pm 7.4)$ & 0.65 \\
& 2.5 & $3.9( \pm 0.9)$ & $6.2( \pm 2.7)$ & 0.62 \\
\hline ETNA & 20 & $20.2( \pm 0.9)$ & $21.6( \pm 3.9)$ & 0.94 \\
& 15 & $14.2( \pm 1.9)$ & $10.5( \pm 3.6)$ & 1.35 \\
& 10 & $9.2( \pm 1.3)$ & $21.5( \pm 3.6)$ & 0.43 \\
& 5 & $4.8( \pm 0.1)$ & $10.3( \pm 2.6)$ & 0.46 \\
\hline \multirow{2}{*}{ WA } & 16 & $16.0( \pm 0.4)$ & $15.2( \pm 2.6)$ & 0.88 \\
& 8 & $8.8( \pm 0.3)$ & $9.9( \pm 1.5)$ & 0.75 \\
& 5.5 & $5.7( \pm 0.4)$ & $7.6( \pm 3.0)$ & 0.77 \\
\hline
\end{tabular}

Table 5. Summarizing the effect of decreasing N : P supply on accumulation of PON, DON, POP and DOP within each experiment. Statistical significance of the individual effect $\left(p<0.05\right.$; denoted by $\left.{ }^{*}\right)$ was tested with linear regression analysis and $p$-values are given in brackets.

\begin{tabular}{lcccc}
\hline & PON build-up & DON build-up & POP build-up & DOP build-up \\
\hline PU & $\downarrow(p=0.053)$ & $\leftrightarrow(p=0.129)$ & $\leftrightarrow(p=0.897)$ & $\uparrow(p=0.411)$ \\
ETNA & $\leftrightarrow(p=0.094)$ & $\leftrightarrow(p=0.625)$ & $\uparrow^{*}(p=0.011)$ & $\uparrow^{*}(p=0.020)$ \\
WA & $\downarrow^{*}(p=0.005)$ & $\downarrow^{*}(p=0.040)$ & $\leftrightarrow^{*}(p=0.771)$ & $?$ \\
\hline
\end{tabular}

$\uparrow$ increase; $\downarrow$ decrease; $\leftrightarrow$ unaffected

controlling microbial production was primarily driven by diatoms, as they dominated mesocosm microbial communities during both experiments (see Fig. 5, this study; Hauss et al., 2012; Franz et al., unpublished results). Organic detritus contributed only marginally to POM, as concentrations of microbial biomass estimated from FCM measurements (living cells) were rather consistent with the POC collected on filters (living cells + organic detritus) (compare Hauss et al., 2012; Franz et al., unpublished results).

The dominance of diatoms can likely be attributed to their fast metabolic reaction including high maximum uptake rates and fast cell division after input of new $\mathrm{N}$ (Fawcett and Ward, 2011). A comparable reaction was already recorded by Ryther and Dunstan (1971), where $\mathrm{NH}_{4}^{+}$enrichment induced strong growth of the diatom Skeletonema costatum, while $\mathrm{P}$ addition resulted in equally poor growth of this species compared to the unamended control. Primary production in coastal upwelling areas, to a major part accomplished by diatoms, has been known for decades to be limited by "newly" supplied N from the deep water (Dugdale, 1985). Thus, it is not surprising that the microbial community in the mesocosm experiments, provided with replete amounts of $\mathrm{Si}(\mathrm{OH})_{4}$ and iron, was regulated by the macronutrient $\mathrm{N}$. Yet, since the cellular assembly machinery of blooming species like diatoms requires large quantities of $\mathrm{P}$ molecules for RNA synthesis, we expected highest growth rates in the $8: 1 \mathrm{~N}: \mathrm{P}$ treatments, which were enriched in $\mathrm{N}$ and $\mathrm{P}$. However, total production of microbial biomass was solely controlled by $\mathrm{N}$ supply and showed no reaction to $\mathrm{P}$ fertilization. Similar responses of natural phytoplankton communities were recorded in another nutrient enrichment experiment performed in the upwelling area off Southern California (Thomas, 1974). A multitude of nutrient fertilization studies were conducted in oligotrophic regions and showed patterns of $\mathrm{N}$ as well as of P limitation (e.g. Graziano et al., 1996; Moore et al., 2008). Although $\mathrm{N}$ was the primary limiting nutrient (see also meta-analysis by Downing et al., 1999), combined additions of $\mathrm{N}$ and $\mathrm{P}$ induced larger increases in microbial biomass compared to providing $\mathrm{N}$ alone. Summarizing results from all these nutrient enrichment experiments, including this study, we can deduce that, under the premise that no other nutrient (e.g. Fe, Si) limits primary production, picoplanktonic communities from nutrient-poor waters tend to be limited by $\mathrm{N}$ and $\mathrm{P}$, whereas microalgal assemblages from upwelling areas are exclusively limited by $\mathrm{N}$. Yet, we have to be careful with generalizing these responses to the bulk of marine non-diazotrophic photoautotrophs, since there is a wide variability among different phytoplankton groups concerning their optimal nutrient conditions (Geider and LaRoche, 2002). For instance, growth of 

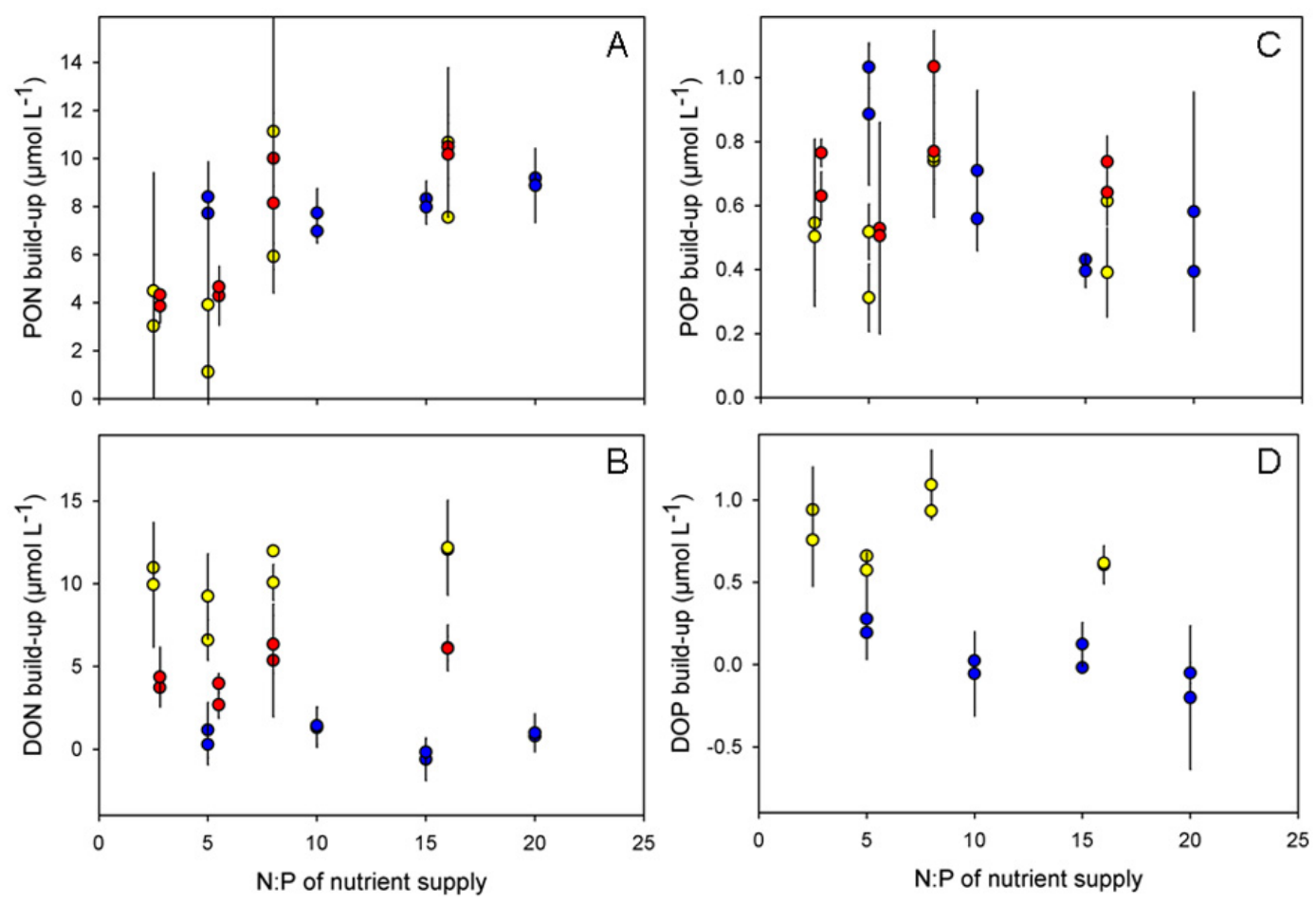

Fig. 8. Build-up of (A) PON, (B) DON, (C) POP and (D) DOP until day one and two after DIN limitation as a function of $\mathrm{N}$ : P stoichiometry of the supplied nutrients during three (PON, DON, POP) or two experiments (DOP). Style and colour-coding according to Fig. 6.

some low-abundant photoautotrophs during the PU experiment was favoured by low $\mathrm{N}$ : P nutrient ratios (Hauss et al., 2012).

Considering the response of the microbial community as a whole, this study gives indications of the key nutrient controls of primary production in coastal upwelling areas and how nutrient assimilation and microbial production of organic matter respond to changes in nutrient inventories.

\subsection{Relationship between $N$ : $P$ supply and microbial $\mathbf{N}$ : P}

Redfield (1958) discovered the average elemental composition of seston and of seawater nutrients to be remarkably similar and suggested a tight coupling between organic matter and nutrient stoichiometry. However, besides the ratio of nutrient supply (Rhee, 1978; Sterner and Elser, 2002), phytoplankton stoichiometry is influenced considerably by growth rate (Goldman et al., 1979). Numerous studies discussed the relation between the physiological growth state and the cellular N:P ratio of phytoplankton (Sterner and Elser, 2002; Klausmeier et al., 2004a, b; Arrigo, 2005). Exponential growth requires an assembly machinery rich in ribosomes, which are characterized by low $\mathrm{N}: \mathrm{P}$. In contrast, equilibrium growth under nutrient limitation is maintained by a metabolism optimized for resource acquisition, consisting mainly of $\mathrm{N}$-rich proteins. Hence, the growth strategy of the cell affects nutrient requirements and ultimately its biochemical composition substantially.

In addition, the growth phase defined by nutrient availability regulates phytoplankton elemental stoichiometry (Klausmeier et al., 2004a and 2008). Elemental ratios of organic matter within the individual experiments showed only minor deviations from each other during exponential growth under high nutrient availability, regardless of the respective $\mathrm{N}: \mathrm{P}$ supply ratio (Fig. 7a). Nutrient saturation allowed cells to "eat what they need" (after Sterner and Elser, 2002), closely matching their specific optimal uptake ratio and constraining organic $\mathrm{N}: \mathrm{P}$ to a relatively narrow range around Redfield's $16: 1$. Under nutrient depletion during the stationary phase, cells consume nearly the entire pool of supplied nutrients, and consequently their elemental composition approached the respective $\mathrm{N}: \mathrm{P}$ input ratio, generating a much wider PON : POP range (Fig. 7b). N : P drawdown ratios obtained from regression analysis also showed that nutrient uptake kinetics of the cells were strongly influenced by the $\mathrm{N}: \mathrm{P}$ supply ratio (Fig. 3). The tight positive correlation between ratios of nutrient supply and organic biomass after nutrient exhaustion indicates a high flexibility of phytoplankton stoichiometry to changes in nutrient supply ratios when absolute nutrient concentrations are low. This response has already been described by culture experiments (Rhee, 1978; Goldman et al., 1979) and model-based data (Klausmeier et al., 2004a). An extremely high or low PON : POP stoichiometry 
under conditions of nutrient limitation is likely to be caused by luxury consumption and intracellular storage of the nutrient ( $\mathrm{N}$ or P) that is not limiting (Goldman et al., 1979; Geider and LaRoche, 2002). Nonetheless, the flexibility of cellular $\mathrm{N}$ : $\mathrm{P}$ is ultimately restricted. Microbial elemental composition seemed to be constrained by a lower ratio of $5: 1$, as biomass was not produced with a PON : POP composition $<5: 1$ (Fig. 6). Using a compilation of published data on the biochemical composition of phytoplankton, Geider and LaRoche (2002) identified also a lower limit for microalgal $\mathrm{N}: \mathrm{P}$ stoichiometry of $5: 1$. Unused residual amounts of DIP in the medium (data not shown) and exudation of excess $P$ (Fig. 8d) are conform with the concept that limits to the cellular storage capacity for nutrients are causing the decoupling of nutrient supply ratio and microalgal elemental composition (Geider and LaRoche, 2002).

A consistent offset between the PON : POP ratio of produced biomass and the $\mathrm{N}: \mathrm{P}$ supply ratio occurred over the entire gradient of $\mathrm{N}: \mathrm{P}$, yet approaching the $1: 1$ line with increasing $\mathrm{N}$ : $\mathrm{P}$ supply (Fig. 6). Thus, the largest offset occurred at the lowest $\mathrm{N}: \mathrm{P}$ supply tested. This deviating trend is partly a result of the unused DIP left in the medium in the $2.5: 1$ and $2.8: 1 \mathrm{~N}: \mathrm{P}$ treatments during the PU and WA trials. Our data indicate that the increased deviation between organic $\mathrm{N}$ : $\mathrm{P}$ build-up and inorganic $\mathrm{N}$ : $\mathrm{P}$ uptake under low $\mathrm{N}$ : $\mathrm{P}$ supply was caused by enhanced transfer of DIP into the DOP pool. Decreasing N:P supply ratios may thereby induce a shift in the partitioning of organic $P$ from the particulate to the dissolved phase. The lower the nutrient $\mathrm{N}: \mathrm{P}$ supply ratio, the more phosphorus may be channelled into DOP instead of being utilized for particulate biomass buildup. With excess $\mathrm{P}$ in the medium (excess $\mathrm{P}=\mathrm{DIP}-\mathrm{DIN} / 16$ ), Conan and colleagues (2007) detected also a significant part (around $80 \%$ ) of assimilated P in the dissolved organic fraction. Already in 1974, Banse highlighted the high importance of dissolved organic compounds in nutrient cycling and in changes of phytoplankton $\mathrm{N}: \mathrm{P}$, as removal of inorganic substances from the medium does not necessarily imply their exclusive incorporation into particulate biomass. For instance, exudation of dissolved fractions of organic material by healthy non-senescent cells is not uncommon (Mague et al., 1980; Myklestad et al., 1989) and may influence organic matter cycling significantly.

\subsection{Effect of different nutrient enrichment on organic matter partitioning}

Changes in the $\mathrm{N}: \mathrm{P}$ supply ratio affected the production of organic nitrogen and phosphorus and their partitioning between the particulate and the dissolved fraction. In the experiment off Peru, decreasing $\mathrm{N}$ : $\mathrm{P}$ supply entailed a reduction in PON accumulation, whereas DON build-up varied only marginally along the gradient of $\mathrm{N}$ : $\mathrm{P}$ supply. Excess $\mathrm{P}$ resulting from decreasing $\mathrm{N}: \mathrm{P}$ supply ratios was transferred into DOP, while POP production remained rather unaffected by an increasing $\mathrm{P}$ availability. Changes in the PON: POP composition under variable nutrient supply in this experiment on the Peruvian shelf were caused by the pools of PON and DOP responding to changing nutrient supply.

In the ETNA experiment, organic nitrogen, neither in the particulate nor in the dissolved phase, was affected by nutrient supply. PON : POP of biomass build-up was solely controlled by changes in the production of POP and DOP in response to variable $\mathrm{N}$ : $\mathrm{P}$ supply ratios. Like in the PU trial, DOP accumulation increased with decreasing $\mathrm{N}: \mathrm{P}$ supply and declined under rising $\mathrm{N}$ : $\mathrm{P}$ conditions, respectively. Phytoplankton cells confronted with P-starvation activate expression of extracellular enzymes such as alkaline phosphatase which are catalyzing hydrolysis of organic phosphorus compounds (Dyhrman and Ruttenberg, 2006; Dyhrman et al., 2006; Ranhofer et al., 2009). Alkaline phosphatase expression and activity is generally stimulated by P-deficiency at concomitant $\mathrm{N}$-repletion. Increases in excess $\mathrm{P}$ may consequently diminish production of this hydrolytic enzyme, as the need for using DOP as a substitute source for nutrition is vanishing. Poor DOP consumption would even allow an enhanced accumulation of organic phosphorus in the dissolved phase, as observed in the Peruvian upwelling. Besides low removal rates (by phytoplankton and/or heterotrophic bacteria), accelerated DOP production via microalgal exudation, cell lysis and zooplankton grazing (Karl and Björkman, 2002) may be the reason for increasing DOP accumulation with decreasing $\mathrm{N}$ : P supply. For example, protozoan grazing has been linked to the transfer of organic phosphorus from the particulate to the dissolved fraction (Dolan et al., 1995). However, more reasonable in conjunction with changes in nutrient inventories seems to be an increased exudation of DOP induced by a form of luxury consumption of $\mathrm{P}$ by the microalgal cells under growing $P$ availability. Luxury uptake of the non-limiting nutrient by phytoplankton typically occurs under nutrient saturation to refill cellular reservoirs for upcoming events of nutrient starvation (Healey, 1973; Geider and LaRoche, 2002; Sarthou et al., 2005). Yet, intracellular accumulation of phosphorus is quantitatively confined and an excess in intracellular phosphorus is disposed via exudation.

Unfortunately, we could not assess the effect of variable nutrient supply on DOP build-up in the experiment conducted on the West African shelf. But since PON production was significantly reduced under low $\mathrm{N}: \mathrm{P}$ supply together with no effect on POP build-up, the growing offset between PON:POP stoichiometry and inorganic N:P was likely induced by enhanced channelling of $P$ into the DOP pool. The general absence of DOP accumulation in the WA experiment may be due to several reasons. Low concentrations could be caused by low DOP release via exudation, grazing or cell lysis. Alternatively, enhanced or reduced removal of DOP could have also affected the magnitude of DOP accumulation. Photoautotrophic microorganisms can utilize certain DOP compounds as an additional $\mathrm{P}$ source (reviewed by Cembella et al., 1984, and by Karl and 
Björkmann, 2002), and especially the filamentous cyanobacterium Trichodesmium is known to grow largely on DOP (e.g. Dyhrman et al., 2002; Sohm and Capone, 2006). The presence of Trichodesmium in the WA experiment and the fact that its abundance increased under exhaustion of DIP (Franz et al., unpublished results) indicate that DOP exuded from blooming diatoms was immediately assimilated by the cyanobacteria. Furthermore, increased abundance of heterotrophic bacteria in the WA experiment (see Table 3) suggests a dynamic and rapid turnover of the organic material, impeding its accumulation in the medium. Differences in the composition of the microbial communities can therefore strongly influence DOP dynamics. It must be further taken into account that DOP can include a multitude of organic compounds that differ considerably in their molecular configuration (Karl and Björkman, 2002). This entails differences in the bioavailability of the various DOP compounds. Small nucleotides (e.g. Adenosintriphosphat) can be easily assimilated, whereas polymers (DNA, RNA) are characterized by long turnover times, resulting in accumulation of DOP in the water column (Thingstad et al., 1993; Björkman and Karl, 1994). Consequently, the biochemical composition of the individual DOP pool determines its bioavailability and is pivotal for its removal by bacteria and microalgae.

In contrast to the PU and ETNA experiments, DON accumulation increased with increasing $\mathrm{N}$ : $\mathrm{P}$ supply off West Africa. This can either be attributed to an enhanced deposition or an impaired removal of DON at high $\mathrm{N}$ supply, or a combination of both. Even though $\mathrm{N}$ was the critical nutrient, saturation presumably stimulated luxury uptake of $\mathrm{N}$ by phytoplankton cells, resulting in a restocking of the intracellular $\mathrm{N}$ reservoirs, but causing also enhanced exudation of DON. High phytoplankton biomass in the N-rich treatments induced most likely development of a large protozoan community, which increased the DON pool via grazing and excretion additionally. DON may have also accumulated due to an impeded removal by phytoplankton and/or heterotrophic bacteria. In fact, DON serves as a nitrogen source for some phytoplankton groups under DIN depletion and especially labile forms of DON are frequently assimilated by photoautotrophs (reviewed by Bronk et al., 2007). But under high DIN availability, the autotrophic cells preferred assimilation of the more bioavailable forms of DIN, promoting accumulation of DON in the medium.

The artificial nutrient enrichment to natural microbial communities from eastern boundary current systems in the shipboard mesocosms can be regarded as a simulated upwelling event, facilitating development of a typical phytoplankton bloom subsequent to nutrient pulses from the deep water. Considerations about shifts of $\mathrm{N}$ and $\mathrm{P}$ between the inorganic, organic particulate and organic dissolved fraction are therefore based on the dominant photoautotrophic community. Heterotrophic bacteria are also known to feed on inorganic and dissolved organic nutrient compounds (Kirchman, 1994), and will certainly influence in particular pools of DON and DOP. Nonetheless, bacterial contributions to the microbial biomass were for the most part considerably lower than by phytoplankton; thus we presume that significant effects in pools of DON and DOP are primarily induced by the response of phytoplankton to variable nutrient supply. Hence, we could show that reservoirs of DON and DOP are indeed affected by the magnitude of $\mathrm{N}$ : $\mathrm{P}$ supply and may thus play an important role in coastal upwelling biogeochemistry under decreasing $\mathrm{N}$ : P supply ratios.

\section{Conclusions}

Against the background of expanding OMZs and the associated increase in $\mathrm{N}$ loss, biogeochemistry of high-productivity upwelling areas overlying $\mathrm{O}_{2}$-deficient intermediate waters may face severe changes in the future. Our results indicate a decline in organic matter production of coastal microbial communities as a result of decreasing $\mathrm{N}$ supply. The observed high flexibility of phytoplankton elemental stoichiometry to variations in the $N: P$ supply ratio suggests a general decrease in the $\mathrm{N}: \mathrm{P}$ composition of primary producers in the upwelling regime in the course of decreasing seawater $\mathrm{N}$ : P. However, phytoplankton N:P seems to have a critical lower limit of about $5: 1$. DIP in excess of this ratio is likely to be transferred into the DOP pool or remains unused in shelf waters. Surface waters departing from the shelf would thus be enriched in DIP and DOP, and might fuel growth of diazotrophic phytoplankton in the oceanic off-shelf regions. High-quality in situ measurements of DOP in surface waters above the $\mathrm{OMZ}$ on the continental shelf and adjacent to the upwelling area are necessary to confirm this hypothesis. Modifications in the cellular N: $\mathrm{P}$ composition also entail a change in the nutritional value of coastal microorganisms as a food source. Effects of changing $\mathrm{N}$ : P supply may therefore also involve higher trophic levels of the pelagic food web.

Acknowledgements. The authors would like to thank technicians Peter Fritsche, Thomas Hansen, Kerstin Nachtigall, Martina Lohmann and the crew of R/V Meteor for their great support during the cruises. We thank Matthias Friebe for technical assistance with DOC and TDN analysis. This work is a contribution of the Sonderforschungsbereich 754 "Climate - Biogeochemistry Interactions in the Tropical Ocean" (www.sfb754.de) which is supported by the German Science Foundation (DFG).

The service charges for this open access publication have been covered by a Research Centre of the Helmholtz Association.

Edited by: G. Herndl 


\section{References}

Arrigo, K. R.: Marine microorganisms and global nutrient cycles, Nature, 437, 349-355, 2005.

Banse, K.: The nitrogen-to-phosphorus ratio in the photic zone of the sea and the elemental composition of the plankton, Deep-Sea Res., 21, 767-771, 1974.

Barlow, R. G., Cummings, D. G., and Gibb, S. W.: Improved resolution of mono-and divinyl chlorophylls $a$ and $b$ and zeaxanthin and lutein in phytoplankton extracts using reverse phase C-8 HPLC, Mar. Ecol. Progr. Ser., 161, 303-307, 1997.

Björkman, K. and Karl, D. M.: Bioavailability of inorganic and organic phosphorus compounds to natural assemblages of microorganisms in Hawaiian coastal waters, Mar. Ecol. Prog. Ser., 111, 265-273, 1994.

Bronk, D. A., See, J. H., Bradley, P., and Killberg, L.: DON as a source of bioavailable nitrogen for phytoplankton, Biogeosciences, 4, 283-296, doi:10.5194/bg-4-283-2007, 2007.

Cembella, A. D., Antia, N. J., and Harrison, P. J.: The utilization of inorganic and organic phosphorous compounds as nutrients by eukaryotic microalgae: A multidisciplinary perspective: Part 1, CRC Crit. Rev. Microbiol., 10, 317-391, 1984.

Codispoti, L. A. and Christensen, J. P.: Nitrification, denitrification and nitrous oxide cycling in the eastern tropical South Pacific ocean, Mar. Chem., 16, 277-300, 1985.

Conan, P., Søndergaard, M., Kragh, T., Thingstad, F., Pujo-Pay, M., Williams, P. J. le B., Markager, S., Cauwet, G., Borch, N. H., Evans, D., and Riemann, B.: Partitioning of organic production in marine plankton communities: The effects of inorganic nutrient ratios and community composition on new dissolved organic matter, Limnol. Oceanogr., 52, 753-765, 2007.

Dolan, J. R., Thingstad, T. F., and Rassoulzadegan, F.: Phosphate transfer between microbial size-fractions in Villefranche Bay $(\mathrm{N}$. W. Mediterranean Sea), France in autumn 1992, Ophelia, 41, 71$85,1995$.

Downing, J. A., Osenberg, C. W., and Sarnelle, O.: Meta-analysis of marine nutrient-enrichment experiments: variation in the magnitude of nutrient limitation, Ecology, 80, 1157-1167, 1999.

Dugdale, R. C.: The effects of varying nutrient concentration on biological production in upwelling regions, CalCOFI Rep., 26, 93-96, 1985.

Dyhrman, S. T. and Ruttenberg, K. C.: Presence and regulation of alkaline phosphatase activity in eukaryotic phytoplankton from the coastal ocean: Implications for dissolved organic phosphorus remineralization, Limnol. Oceanogr., 51, 1381-1390, 2006.

Dyhrman, S. T., Webb, E., Anderson, D. M., Moffett, J., and Waterbury, J.: Cell specific detection of phosphorus stress in Trichodesmium from the Western North Atlantic, Limnol. Oceanogr., 47, 1823-1836, 2002.

Dyhrman, S. T., Chappell, P. D., Haley, S. T., Moffett, J. W., Orchard, E. D., Waterbury, J. B., and Webb, E. A.: Phosphonate utilization by the globally important marine diazotroph Trichodesmium, Nature, 439, 68-71, 2006.

Falkowski, P. G.: Rationalizing elemental ratios in unicellular algae, Journal of Phycology, 36, 3-6, 2000.

Fawcett, S. E. and Ward, B. B.: Phytoplankton succession and nitrogen utilization during the development of an upwelling bloom, Mar. Ecol. Progr. Ser., 428, 13-31, 2011.

Franz, J., Krahmann, G., Lavik, G., Grasse, P., Dittmar, T., and Riebesell, U.: Dynamics and stoichiometry of nutrients and phy- toplankton in waters influenced by the oxygen minimum zone in the eastern tropical Pacific, Deep-Sea Res. Part I, 62, 20-31, 2012.

Franz, J. M. S., Hauss, H., Löscher, C. R., and Riebesell, U.: Impact of changes in dissolved nutrient in the eastern tropical North Atlantic I: phytoplankton growth and community structure, unpublished results.

Geider, R. J. and LaRoche, J.: Redfield revisited: variability of $\mathrm{C}: \mathrm{N}: \mathrm{P}$ in marine microalgae and its biochemical basis, Eur. J. Phycol., 37, 1-17, 2002.

Gervais, F. and Riebesell, U.: Effect of phosphorus limitation on elemental composition and stable carbon isotope fractionation in a marine diatom growing under different $\mathrm{CO}_{2}$ concentrations, Limnol. Oceanogr., 46, 497-504, 2001.

Goldman, J. C., McCarthy, J. J., and Peavey, D. G.: Growth-rate influence on the chemical composition of phytoplankton in oceanic waters, Nature, 279, 210-215, 1979.

Graziano, L. M., Geider, R. J., Li, W. K. W., and Olaizola, M.: Nitrogen limitation of North Atlantic phytoplankton: Analysis of physiological condition in nutrient enrichment experiments, Aqua. Microb. Ecol., 11, 53-64, 1996.

Hansen, H. P. and Koroleff, F.: Determination of nutrients, in: Methods of seawater analysis, 3.Ed., edited by: Grasshoff, K., Kremling, K., and Erhardt, M., Wiley VCH, Weinheim, 159-228, 1999.

Hauss, H., Franz, J. M. S., and Sommer, U.: Changes in N:P stoichiometry influence taxonomic composition and nutritional quality of phytoplankton in the Peruvian upwelling, J. Sea Res., 73, 74-85, 2012.

Healey, F. P.: Inorganic nutrient uptake and deficiency in algae, $\mathrm{Cr}$. Rev. Microbiol., 3, 69-113, 1973.

Helly, J. J. and Levin, L. A.: Global distribution of naturally occurring marine hypoxia on continental margins, Deep-Sea Research Part I: Oceanographic Research Papers, 51, 1159-1168, 2004.

Hillebrand, H., Dürselen, C. D., Kirschtel, D., Pollingher, U., and Zohary, T.: Biovolume calculation for pelagic and benthic microalgae, J. Phycol., 35, 403-424, 1999.

Holmes, R. M., Aminot, A., Kérouel, R., Hooker, B. A., and Peterson, B. J.: A simple and precise method for measuring ammonium in marine and freshwater ecosystems, Can. J. Fish. Aquat. Sci., 56, 1801-1808, 1999.

Karl, D. M. and Björkman, K. M.: Dynamics of DOP, in: Biogeochemistry of Marine Dissolved Organic Matter, edited by: Hansell, D. A. and Carlson, C. A., Academic Press, San Diego, 250-366, 2002.

Keeling, R. F. and Garcia, H. E.: The change in oceanic $\mathrm{O}_{2}$ inventory associated with recent global warming, P. Natl. Acad. Sci., 99, 7848-7853, 2002.

Kerouel, R. and Aminot, A.: Fluorometric determination of ammonia in sea and estuarine waters by direct segmented flow analysis, Mar. Chem., 57, 265-275, 1997.

Kirchman, D. L.: The uptake of inorganic nutrients by heterotrophic bacteria, Microb. Ecol., 28, 255-271, 1994.

Klausmeier, C. A., Litchman, E., and Levin, S. A.: Phytoplankton growth and stoichiometry under multiple nutrient limitation, Limnol. Oceanogr., 49, 1463-1470, 2004a.

Klausmeier, C. A., Litchman, E., Daufresne, T., and Levin, S. A.: Optimal nitrogen-to-phosphorus stoichiometry of phytoplankton, Nature, 429, 171-174, 2004b. 
Klausmeier, C. A., Litchman, E., Daufresne, T., and Levin, S. A.: Phytoplankton stoichiometry, Ecol. Res., 23, 479-485, 2008.

Koroleff, F.: Simultaneous persulphate oxidation of phosphorus and nitrogen compounds in water, in: Report of the Baltic Intercalibration Workshop, edited by: Grasshoff, K., Annex Interim Commission for the Protection of the Environment of the Baltic Sea, 52-53, 1977.

Kuypers, M. M. M., Sliekers, A. O., Lavik, G., Schmid, M., Jorgensen, B. B., Kuenen, J. G., Sinninghe Damste, J. S., Strous, M., and Jetten, M. S. M.: Anaerobic ammonium oxidation by anammox bacteria in the Black Sea, Nature, 422, 608-611, 2003.

Luyten, J. R., Pedlosky, J., and Stommel, H.: The Ventilated Thermocline, J. Phys. Oceanogr., 13, 292-309, 1983.

Mackey, M. D., Mackey, D. J., Higgins, H. W., and Wright, S. W.: CHEMTAX - a program for estimating class abundances from chemical markers: application to HPLC measurements of phytoplankton,Mar. Ecol. Prog. Ser., 144, 265-283, 1996.

Mackey, M. D., Higgins, H. W., Mackey, D. J., and Wright, S. W.: CHEMTAX User's Manual: A Program for Estimating Class Abundances from Chemical Marker - Application to HPLC Measurements of Phytoplankton Pigments, CSIRO Marine Laboratories Report 229, Hobart, Australia, 47 pp., 1997.

Mague, T. H., Friberg, E., Hughes, D. J., and Morris, I.: Extracellular release of carbon by marine phytoplankton: A physiological approach, Limnol. Oceanogr., 25, 262-279, 1980.

Matear, R. J. and Hirst, A. C.: Long-term changes in dissolved oxygen concentrations in the ocean caused by prottracted global warming, Global Biogeochem. Cy., 17, 1125, doi:10.1029/2002GB001997, 2003.

Menden-Deuer, S. and Lessard, E. J.: Carbon to volume relationships for dinoflagellates, diatoms, and other protist plankton, Limnol. Oceanogr., 45, 569-579, 2000.

Moore, C. M., Mills, M. M., Langlois, R., Milne, A., Achterberg, E. P., LaRoche, J., and Geider, R. J.: Relative influence of nitrogen and phosphorus availability on phytoplankton physiology and productivity in the oligotrophic sub-tropical North Atlantic Ocean, Limnol. Oceanogr., 53, 261-305, 2008.

Myklestad, S., Holm-Hansen, O., Vârum, K. M., and Volcani, B.: Rate of release of extracellular amino acids and carbohydrates from the marine diatom Chaetoceros affinis, J. Plankton Res., 11, 763-773, 1989.

Ranhofer, M., Lawrenz, E., Pinckney, J., Benitez-Nelson, C., and Richardson, T.: Cell-specific alkaline phosphatase expression by phytoplankton from Winyah Bay, South Carolina, USA, Estuar. Coast., 32, 943-957, 2009.

Redfield, A. C.: The biological control of chemical factors in the environment, Am. Sci., 46, 205-221, 1958.
Reid Jr. J. L.: Intermediate waters of the Pacific Ocean, Johns Hopkins Oceanographic Studies, 2, 85, 1965.

Rhee, G. Y.: Effects of N-P Atomic ratios and nitrate limitation on algal growth, cell composition, and nitrate uptake, Limnol. Oceanogr., 23, 10-25, 1978.

Ryther, J. H. and Dunstan, W. M.: Nitrogen, phosphorus, and eutrophication in the coastal marine environment, Science, 171, 1008-1013, doi:10.1126/science.171.3975.1008, 1971.

Sarthou, G., Timmermans, K. R., Blain, S., and Tréguer, P.: Growth physiology and fate of diatoms in the ocean: a review, J. Sea Res. 53, 25-42, 2005.

Sharp, J. H.: Improved analysis for particulate organic carbon and nitrogen from seawater, Limnol. Oceanogr., 19, 984-989, 1974.

Sohm, J. A. and Capone, D. G.: Phosphorus dynamics of the tropical and subtropical north Atlantic: Trichodesmium spp. versus bulk plankton, Mar. Ecol. Progr. Ser., 317, 21-28, 2006.

Sterner, R. W. and Elser, J. J.: Ecological stoichiometry. The biology of elements from molecules to the biosphere, Univ. Press, Princeton, NJ [u.a.], XXI, 439 pp., 2002.

Suess, E.: Phosphate regeneration from sediments of the Peru continental margin by dissolution of fish debris, Geochim. Cosmochim. Ac., 45, 577-588, 1981.

Thamdrup, B. and Dalsgaard, T.: Production of $\mathrm{N}_{2}$ through anaerobic ammonium oxidation coupled to nitrate reduction in marine sediments, Appl. Environ. Microbiol., 68, 1312-1318, doi:10.1128/aem.68.3.1312-1318.2002, 2002.

Thingstad, T. F., Skjodal, E. F., and Bohne, R. A.: Phosphorus cycling and algal-bacterial competition in Sandsfjord, western Norway. Mar. Ecol. Prog. Ser., 99, 239-259, 1993.

Thomas, W. H., Seibert, D. L. R., and Dodson, A. N.: Phytoplankton enrichment experiments and bioassays in natural coastal sea water and in sewage outfall receiving waters off Southern California, Estuar. Coast. Mar. Sci., 2, 191-206, 1974.

Utermöhl, H.: Zur Vervollkommnung der quantitativen Phytoplankton Methodik, Mitteilungen der Internationalen Vereinigung für Theoretische und Angewandte Limnologie, 9, 263-272, 1958.

Van Cappellen, P. and Berner, R. A.: A mathematical model for the early diagenesis of phosphorus and fluorine in marine sediments; apatite precipitation, Am. J. Sci., 288, 289-333, 1988.

West, J. A. and McBride, D. L.: Long-term and diurnal carpospores discharge patterns in the Ceramiaceae, Rhodomelaceae and Delesseriaceae (Rhodophyta), Hydrobiologia, 298/299, 101-113, 1999.

Wurl, O. and Min Sin, T.: Analysis of dissolved and particulate organic carbon with the HTCO technique, in: Practical Guidelines for the Analysis of Seawater, edited by: Wurl, O., CRC Press, Boca Raton, 33-48, 2009. 